\title{
Portrayal of Aasia Bibi Blasphemy Case: A Comparative Analysis of News Headlines in Pakistani Newspapers
}

\author{
Khushboo Rafiq \\ Lecturer \\ Department of Media and Communication Studies \\ Sindh Madressatul University \\ Karachi, Pakistan \\ khushboo@smiu.edu.pk \\ Abdul Bari \\ Student \\ Department of Media and Communication Studies \\ Sindh Madressatul University \\ Karachi, Pakistan \\ bariabdul092@gmail.com \\ Muhammad Kamil Lakho \\ Lecturer \\ Department of Social Development \\ Sindh Madressatul University \\ Karachi, Pakistan \\ mkamil@smiu.edu.pk
}

\begin{abstract}
Language is a tool used for the social construction to frame public opinion. The study highlights that newspapers shape, reshape and manipulate the news headlines by representing them differently to achieve the desired objectives. This paper aims to investigate the coverage of Pakistani newspapers on Aasia Bibi's acquittal decision by the Supreme Court of Pakistan. Content analysis considering Dijk Model and Framing Theory was conducted for the purpose. Unit of analysis was the news headlines of four famous dailies of Pakistan i.e., Daily Dawn, The Nation, Daily Jang and Daily Ummat published in the week of judgment of Aasia Bibi Case. Results revealed that the newspapers portrayed the same issue differently with the distinct discursive techniques. The Nation used lexical choices and emotional phrases to mold public opinions. Comparatively,
\end{abstract}




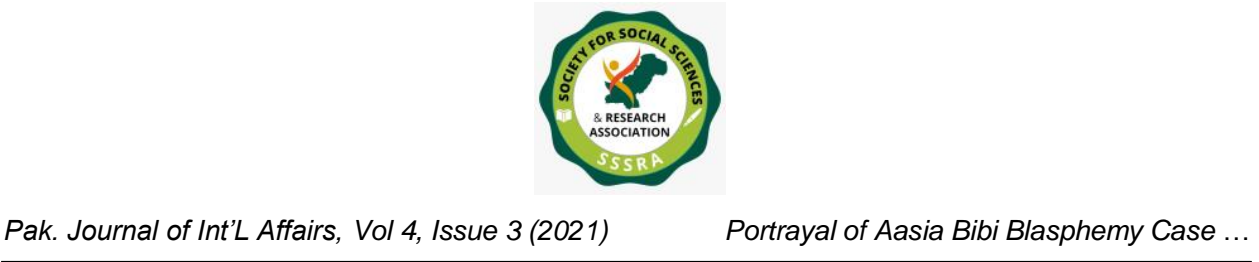

Jang and Dawn were more objective and sensible in publishing its news headlines.

Keywords: Print Media, Newspaper Reporting, Blasphemy, Comparative Analysis, Headlines.

\section{Introduction}

Newspapers are one of the main sources of information in this digital age. They help the general masses to understand the important issues and to construct opinions. After television, reading newspaper is an activity that is in the daily routine of most of the people. It is understood that this works as a window for them. In newspapers, the news is considered as an influential space which shows the accurate and important piece of information (Cottle, 2000; Fowler, 1991). However, the word "news" is very difficult to define. Scholars have given many definitions which vary from one another and yet none is the satisfactory one. According to Reah (2002), news is a term that defines and gives the information about any recent happening that has an impact on the lives of the various people and groups and may be of interest for the people whereas the Tuchman (1976) defined the term news as a constructed reality while Cohen and Young (1973) argued that the news is a product that is being manufactured by the journalists based on some real incident.

Within news, the headlines are considered as an essential part that not only help to attract the readers but follows the newspaper policy of the concerned institution. Traditionally, the newspaper headlines are short and often used as the crux of their news events. Nir (1993) differentiated between the news and headline which suggests that the news is the summary of the story, and the headline is an element that rather summarizes that story and promotes the single detail of that story. However, researchers in various studies have found a difference in covering up a single issue from different perspectives as the ideology of the newspapers. Dor (2003) highlighted that the readers tend to understand and interpret the headlines to optimally ration processing effort with the cognitive effects, with the help of relevance theory. This shows that appropriate and successful headlines are based on the understanding of reader's knowledge, ideology, norms, beliefs and cognition ability.

Dearing and Rogers (1996) defined that the media discourse has an ability to construct the power relations through the specific usage of the language and texts. It can be done through anything like framing of the images and the positioning and extensive communication on a specific issue. A journalist's role in that is to be independent in any 


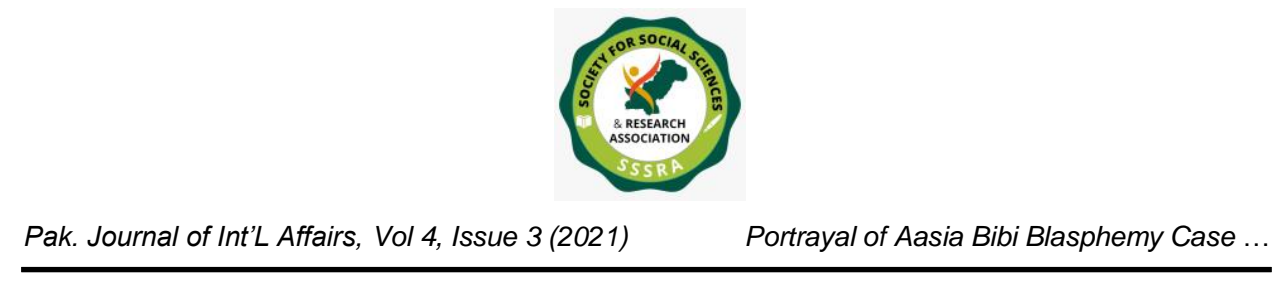

conflict and issue rather than promoting a certain cause, whereas Harcup (2002) argued that the journalists are often caught in a situation where they need to fulfill the desires and demand of the media owners and the employees. To comply with the demands, headlines reflect the perspective of the controlling powers that have an influence upon the actual news event.

Ali (2011) analyzed the news headlines with the help of Van Dijk Model and Wodak's Historical Approach to evaluate the coverage of the death of Saddam Hussain. The researcher found a clear difference in the headlines of those Arab Newspapers who were not under the United States influence and those who were allies of the Washington. Local Arab newspapers supported Saddam Hussain and all his acts against the United States while the rest of the newspapers were against that. Among the five newspapers, it was found that all of them covered the same issue in different manners as per their respective ideological orientation.

\section{Overview of blasphemy law and Aasia Noreen case}

According to the definition by Merriam-Webster (2020), the term blasphemy is defined as "the act of insulting or showing contempt or lack of reverence for God". In other words, it can be stated that it is the reverence towards anything sacred or inviolable. Blasphemy law was made by the British to protect the religious sentiments of the minorities before the partition of Indo-Pak subcontinent. After partition, the law was added in the Pakistan Penal Code.

Chapter fifteen of the Pakistan Penal Code discusses the offences related to religion. This section covers various issues including the acts against the worship places and the deliberate acts that utters and injure religious sentiments (Malik, 2017). Section 295 for which the Aasia Noreen was charged was first introduced in 1927. This came after the judgment of the Lahore High Court on a publication of a book entitled "Rangeela Rasool". This book was written by Krishan Prashaad and published by Raj Pal publications in 1923. The movement against this book was initiated by the Muslims of India to put a ban on the book which they believe is offensive to the life of Holy Prophet. This section 295 includes three sub-sections A, B and C, which first came in the Pakistan's law in 1980s in the regime of General Zia-ul-Haq (Noorani, 1990). Aasia Noreen was charged for Section 295-C which deals with the derogatory remarks in respect of Holy Prophet. However, Eijaz (2010) believes that the interpretation and application of the Blasphemy laws in Pakistan can be a reason for the divides and the conflict in the society. 


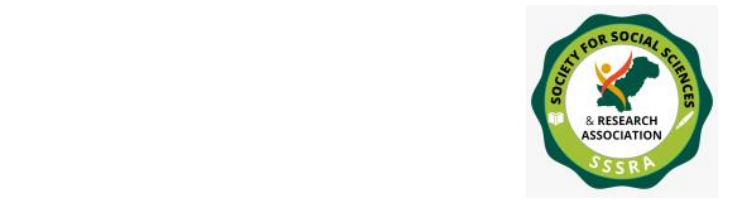

Portrayal of Aasia Bibi Blasphemy Case ...

In 2009, Aasia Noreen commonly known as (Aasia Bibi or Aasia Masih), a Christian woman became famous worldwide when she was accused of the blasphemy and convicted to death in 2010. She was working as a farmhand in a farm field of the village named Ittan Wali. During her work, she was asked by the landowner to fetch water. She followed the order but the other Muslim women who were working on the field refused to touch the bowl and drink as it was touched by a Christian, so it was considered as unclean, and it was propagated as a sin to drink that water.

After few days, a mob in the influence of the local religious scholar was initiated and she was accused of doing blasphemy against the Holy Prophet Muhammad. Aasia Bibi was taken to the police station. She was charged for the blasphemy charges under section 295$\mathrm{C}$ of Pakistan Penal Code. Later, she was convicted for the death by the local court of the Sheikhupura. The decision was upheld by the Lahore High Court as well.

The international community including the world human rights organizations repeatedly asked the Pakistani authorities to not executing the court's verdict. Various petitions were created by the human rights organizations including the one which got 4 lac signatures (Polymenopoulou and Rehman, 2013).

Later, the appeal against the Lahore High Court decision was sent to the Supreme Court of Pakistan by his husband. On 31st October 2018, the Supreme Court of Pakistan acquitted Aasia Noreen or Aasia Bibi citing the contradiction in statements of the witnesses and the material evidence. This decision sparked the protests by the Islamists religious and political parties in the country (Dawn, 2018). On Jan 2019, the petition against the Aasia's acquittal was rejected which was the last legal hurdle in leaving the country. Aasia Bibi was the first woman who was sentenced to death under blasphemy laws (Dawn, 2019).

\section{Research Questions}

1. Whether Pakistani Newspapers have given salience to the Aasia Masih Acquittal Verdict? If yes, then to what extent?

2. What were the perspectives of different newspapers portraying the same issue?

\section{Objectives of the Study}

- To examine the headlines based on Aasia Bibi Case.

- To observe the differences in portraying the same issue through newspapers coverage.

- To investigate the frames that have been used for the portrayal of the issue.

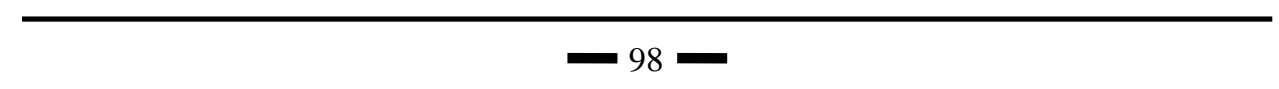




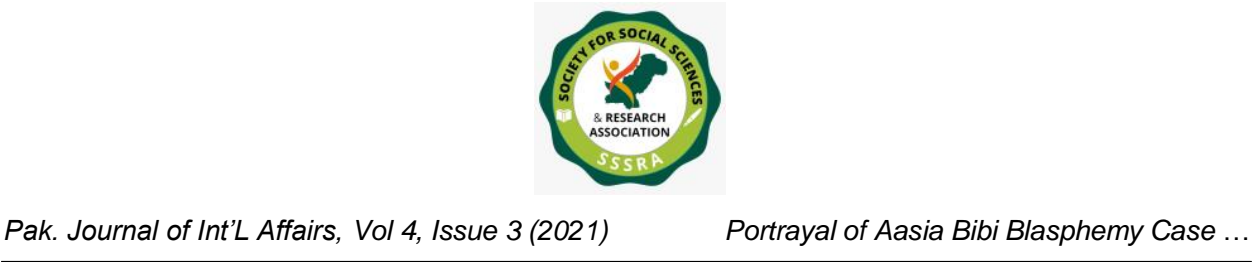

\section{Theoretical Framework}

This research study has its theoretical background and linkages with the Dijk Model of Discourse Analysis and Framing theory.

\section{DIJK model of discourse analysis}

A model of discourse analysis was proposed by the Dijk (2006) in his work "Politics, Ideology and Discourse". According to Dijk, the print media discourse is vital and most suitable tool to propagate the desire ideologies in the masses. This not only helps to frame public opinion but through the linguistic spins, it politicizes the event. He believes that the analysis often carries two types of the discourse i.e., power within discourses and power behind discourses.

In different domains, both the written and spoken texts are analyzed to know the hidden ideological orientations and inclinations of the media discourse. The media discourse is based on the social aspects and factors including the political, historical and geographical elements. Dijk (1998) has given an effective framework to analyze the print media discourse considering his socio-cognitive framework. He believes that the media discourse is very much dependent and inclined based on its cultural, political and social contexts.

\section{Framing theory}

Framing of the media contents means to present and interpret the things in their desired perspectives by highlighting some of the aspects of the story and neglecting others. The framing theory suggests that the media focus on the certain important subjects within their own field of meaning and understanding (Chyi \& McCombs, 2004). The concept of the framing lies in the process of communication. Communication is not static but dynamic that involves the frame building and frame setting.

The founding father of frame analysis, Goffman (1974) has described the framing as cognitive structure which makes the individual to notice the things and leads to define the situations for an individual. Entman (1993) has described the frame as the communicating text or messages which promotes the desired aspect and fact of the perceived reality. He noted that the frames have various locations, including the person or communicator, the text and the one who have received the text.

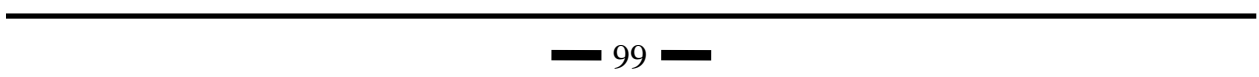




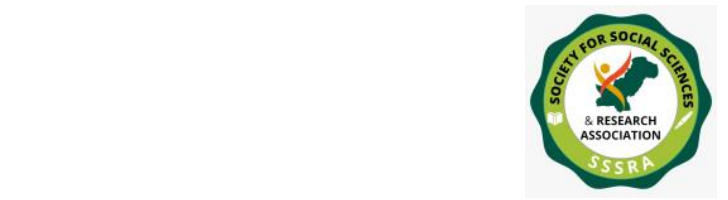

Portrayal of Aasia Bibi Blasphemy Case ...

Gitlin (1980) defined the term news frame as "persistent patterns of cognition, interpretation, presentation, selection and exclusion by which the discourse is organized". Gamson and Modigilani (1989) believe that the framing is an interpretative package of the issue. Behind this package, there is a central organizing idea or frame for suggesting the audience that what is the issue.

\section{Review of the Literature}

There are number of studies which have already been conducted on the news headlines, from structural patterns to experimental studies (Bell, 1991; Kwon, 2002). However, the researchers found a gap in Quirk et al. (1995) to analyze the news headlines in diverse themes and categories including the syntactic features.

According to Jiwani (2006) newsworthiness in the news is a thing that makes the news story worth telling but (Chermak, 1995) believes that this criteria differs from person to person, may be a story for someone may not be a newsworthy story for someone else. Greer (2003) believes that the events are seen culturally, and, in this situation, the cultural proximity plays the vital role in making something newsworthy.

Newspapers constitute and enforce their ideology through their news headlines. A research study was conducted by the Rotimi Taiwo (2007) on three hundred Nigerian headlines to examine the power relations and its sustainability through headlines. The large data of the news headlines were based on politics having more focus on crime. The researcher found that some headlines were completely blunt and adopt the tome of confrontation. It was found that the headlines were used to establish the power relations and ideology among its readers.

Ferman (2013) analyzed the news reporting of the Irish parade in different scenarios and ideological frames. The study identified two different frames which were based on the Catholic/Nationalists and the Protestant/Loyalist frame of the parade. Although, the news headlines were based on the same event, researcher found a difference in the news headlines in terms of text and the presentation of the double meaning words and themes. Similarly, Fang (2001) found the ideological differences in two Chinese newspapers where they differ in reporting the same event. The difference was found in the lexical choices and syntactic structure of the text. Besides that, Cooky et al. (2013) conducted a research study on the news coverage of South African athlete named Caster Semenya in the IAF World Championship 2009. The media supported the questions on the gender questioning of the athlete. Both sides supported the ideologies and the framing of the event from different perspectives. 


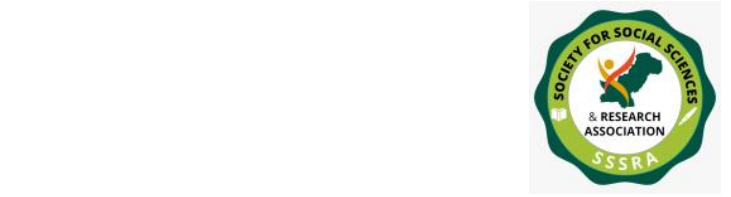

Portrayal of Aasia Bibi Blasphemy Case ...

Sajid et al. (2019) analyzed the randomly selected news headlines based on the political theme in Daily Dawn and The Nation to find about the misrepresentation of the political events. They examined the same political event through the news headlines in both newspapers. The finding of the study reveals that the newspapers have used different discursive techniques and misrepresented the same event in different manners. It was highlighted that even the news headlines are not ideologically free, but the editors use language as a tool to propagate and include in and out groups as per their ideological inclinations.

Kirange and Deshmukh (2016) conducted a research study based on sentiment analysis for the stock price prediction. The researcher employed a predictive model and collected the data from the press releases and regular financial news headlines. Data for this research study were gathered from Wall Street Journal, Reuters, CNBC, NDTV, Hindustan Times, Economic Times, Times of India, Telegraph, CNN Money, Market Watch and Fortune. The researcher found the accuracy of the predictive model very much satisfactory. The comparison between the positive sentiments and the stock price shows the strong correlations between them.

Teo (2000) in his research study on the racism in news based on Australian newspapers reporting found an evidence of systematic way of stereotyping of the ethnic minorities by the white majority. The researcher analyzed the two famous newspapers The Sunday Morning Herald and The Daily Telegraph. The analysis and evidence suggest that there is a racist ideology in the power relations discourse between the ethnic minority and the white majority.

Shah and Mubarak (2002) examined the news headlines of the newspapers on the Model Town tragedy through the critical discourse analysis model. The analysis was based on three-dimensional model which limited this research study to textual and socio-cultural practices only. It was found that the newspapers gave the same news from different angles. The selected newspaper i.e. The News covered the event as clash between police and protesters while the Dawn used the word raid in their headline. Both the newspapers gave a different ideological positioning in the case. Researcher also found the rewording and overworking in the news headlines.

Khodabandeh (2007) conducted a contrastive analysis of English and Persian news headlines. The researcher analyzed the corpus of one-week of both the English and Persian languages where he analyzed lexical features of the news headlines. Results of the study showed that the newspapers were similar in the usage of verbs, active voice, short words but the headline types, structure, form of the tense but the omission of the 


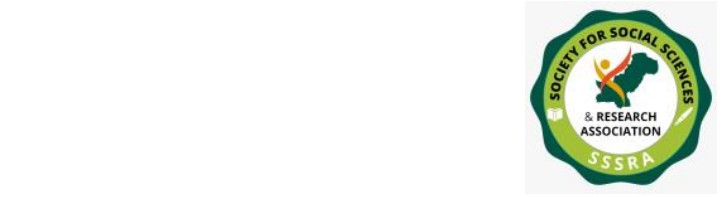

Portrayal of Aasia Bibi Blasphemy Case ...

words were entirely different. This shows how the newspapers play with the language that eventually leads the scenarios based on another perspectives. Similarly, Lee (2012) based on the linguistic variations analyzed the English News Headlines in United States and Korea. The research study was designed to analyze the influence on the news headlines by the extra-linguistic factors as well. Results unveiled that the difference between English news headlines in both countries were attributed with reference to the language, states, beliefs, interests and the ideology. Findings also followed a similarity in the usage of variety of structural patterns in both states.

Neigar (2007) proved his argument that the news headlines are often influenced by different social, political and cultural factors. He put his argument in the light of the Gulf War when there was an increase in the speculative headlines. However, Lee (2009) and Shie (2011) evaluated the news headlines in various diverse approaches. Shie (2011) observed that the American news headlines use more metaphors than their normal EFL version in Taiwan which customizes the headlines for their readers.

A research study was carried out by Ulum (2016) on the Syrian refugees based on the newspaper headlines. This research study was cross cultural with the perspective of ideology in the light of the CDA framework. Results of the study revealed that the western editors presented the issue in the European context that how they can withstand in such situation while Turkish media highlighted the same issue in terms of the grievances and bad conditions that were being faced by the refugees especially when they were enroute towards Europe. Similarly, Gopang and Bughio (2015) made a comparison of the news headlines of English, Urdu and Sindhi language newspapers on the budget of 2013-2014 presented by Pakistani government. With the help of the various discursive strategies and themes, researchers noted that the news headlines were often being presented on the ideological perspectives and orientation of the society. They found a massive change in the perspectives of the news headlines and observed that the editors had used the bombarded vocabulary to propagate the desired political narratives.

\section{Methodology}

The media discourse research has become more interpretative and contextual with differences to the meanings lie beneath the surface and ideologies. This research study is qualitative in nature in which content analysis method is employed to know the differences and framing of the newspapers while covering a same issue i.e., Aasia Bibi Blasphemy Case. Four famous national daily newspapers two in English and two in Urdu language including Daily Dawn, The Nation, Daily Jang and Daily Ummat were selected for the content analysis. The rationale behind choosing these newspapers is because of 


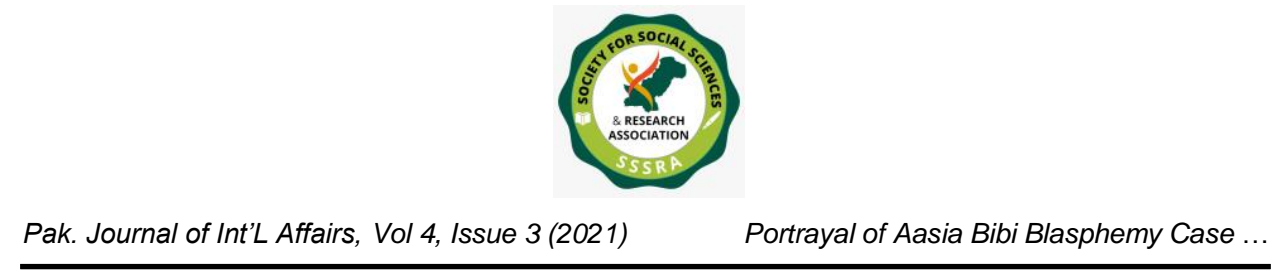

their wide circulation, credibility and the readership including the stakeholders and luminaries. The unit of analysis for this research study was based on a week i.e., $29^{\text {th }}$ October 2018 to $4^{\text {th }}$ November 2018 when the judgment of Aasia Bibi Case was announced. Purposively selected seventeen similar news headlines from above mentioned newspapers were considered for the discourse analysis.

Data for the research study were gathered through the online sources of the concerned newspapers. In this research study, news headlines of the four newspapers are analyzed based on their subjective comments and ideological inclinations to examine the framing and the use of linguistic tactics to shape public opinions in the light of Dijk Model of discourse analysis. Researchers analyzed the news headlines on the Dijk Model which consists of the analytical categories like actor, lexicalization, preposition, categorization, authority, hyperbole, evidentiality, victimization, disclaimer and polarization subject to their availability in the news headlines of the newspapers.

\section{Data Analysis and Discussion}

This section deals with the analysis of the news headlines of four famous dailies of Pakistani print media in the light of Dijk Model of discourse analysis. This section shows the representation of the same event in different manner with the help of different discursive techniques. Findings of this research study show an equal number of news reports in the week of judgment on Aasia Masih case and its aftershocks.

\section{English News Headlines}

\section{Headline 01}

\section{Dawn}

"Capital on high alert as Aasia Bibi appeal verdict today"

\section{The Nation}

"SC to announce verdict in Aasia case today"

The context of these headlines is of the same day when the judgment was going to be announced by the Supreme Court of Pakistan in Aasia Masih Case. It is a pre-judgment new headline which shows the importance of case and the situation. As Fang (2001) discussed that the same news event has been represented with different discursive practices. 


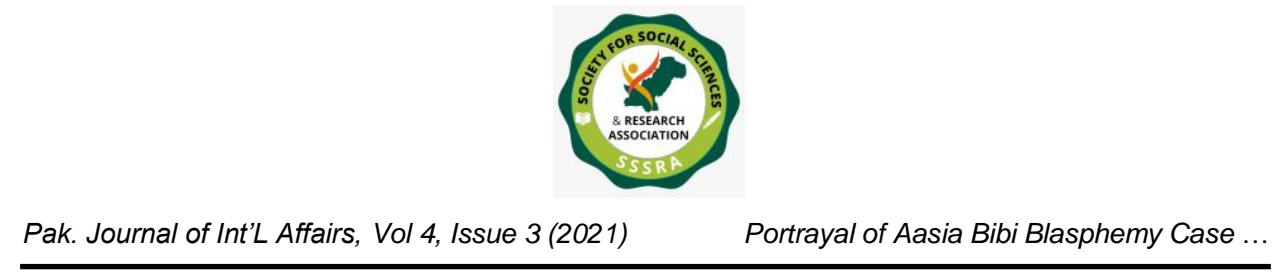

The Daily Dawn covered the news story in two different dimensions where they highlighted the risk and the situation by using the word "Capital on High Alert" which helps the readers to understand the importance and the critical situation that can be caused through this. Dawn covered two different perspectives of security and verdict in the same headline. However, The Nation reported the same event in simplistic manner by just publishing a headline showing the verdict is going to announce today. The other aspect that is pertinent to note here is the use of a word "appeal" which has not been used by the Daily Nation in their headline. This clarifies the fact that this verdict is on an appeal on the earlier case that eventually gives more information in indirect manner. It is observed that the Daily Dawn has given more information to its readers in their headlines as compared to the other newspaper.

Actor: Aasia Bibi

Authority: Supreme Court

Presupposition: announce, today

Lexicalization: High Alert

Preposition: to, on, in, as

To represent the same event in different discursive manner, Dawn used the lexicalization in the form of the word "High Alert". According to Merriam-Webster (2020), the word "alert" means to be watchful and prompt to respond in hard conditions. This clears the point that the situation may be worse so the things should be quick and in state of readiness to respond in any critical situation. Both the newspaper used the same presupposition and authority. However, the usage of prepositions in both headlines was different. It was observed that the Daily Dawn represented the actor as "Aasia Bibi" while the Daily Nation portrayed the actor as half name "Aasia". This shows how the newspaper framed the event by just using the few prepositions and the lexicalization in the news headlines. Flower (1991) defines that the news reporter reconstructs the reality of the event by representing it with different discursive techniques.

\section{Headline 02}

\section{Dawn}

"SC acquits Aasia of blasphemy chargers, orders her release"

\section{The Nation}

"SC acquits Aasia"

Sub-Headline: "Having spent years in jail, 50-year-old receives news with disbelief" Actor: Aasia

Authority: Supreme Court 


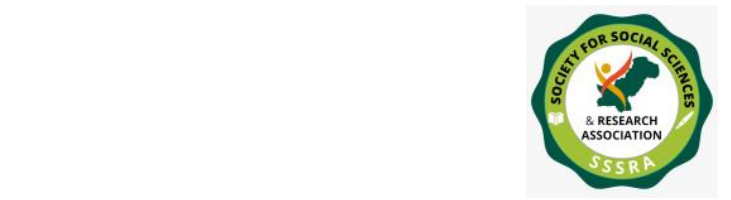

Portrayal of Aasia Bibi Blasphemy Case ...

Preposition: of, in, with
Metaphor: 50-year-old

These news headlines are in context of the verdict announced by the Supreme Court of Pakistan to acquit Aasia Masih from blasphemy charges and ordering her release. Once again, the comparative analysis of both the news headlines shows that Dawn published more information in its news headline while the Daily Nation used the simple statement as information for the readers. It is clearly written that the Dawn has told its readers that what the case was about and the verdict by focusing more on the release.

However, it was observed that the Daily Nation published a supporting sub-headline to its main headline by mixing the statement of Aasia Masih with a fact. Aasia gave the statement from prison that she cannot believe about the news of her release. The nation by combining this statement with the fact of being kept in jail of years used an emotional sentence in the sub-headline. Dijk Model (2006) describes that through the number game, the facts and figures make the statement more concrete. The model suggests that the hyperbole which is used is to exaggerate the statement or the event. It was observed the Nation exaggerated the statement of Aasia Bibi by using the hyperbole and evidentiality.

The newspaper used her age to represent her which twisted the actual statement.

\section{Headline 03}

\section{Dawn}

"Country-wide protests erupt against SC ruling on Aasia Bibi"

\section{The Nation}

"Protests paralyse cities"

These news stories were published in the context of the protests carried out by the religious parties against the Supreme Court's verdict on the Aasia Bibi appeal on her blasphemy charges. Both the newspapers again represented the same event with different discursive techniques and linguistic words.

Lexicalization: erupts

Evidentiality: ruling

Preposition: on

Punctuation: Hyphen (-) 


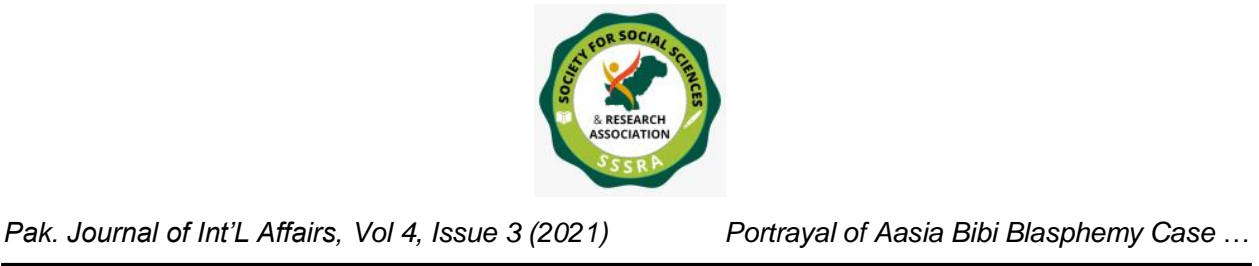

The result shows that the Daily Nation has used the word "paralyses" while the Daily Dawn has covered the aspect in the word "erupt". Using the more specific information, the Dawn covered the information more than Daily Nation.

According to Merriam-Webster (2020), the word "paralyse" which can be defined as the state which makes the condition powerless or ineffective and the "erupt" means to burst out from the limits and restrictions. Dawn used the name Aasia Bibi and the fact of the Supreme Court ruling in the headline while The Nation covered the same event differently with lexicalization of the word paralyse.

\section{Headline 04}

\section{Dawn}

"PM warns protesters against confronting state"

\section{The Nation}

"Don't test State's patience, PM warns protesters"

\section{Actor: State}

Authority: Prime Minister

Lexicalization: confronting

Polarization: Protesters

Punctuation: Apostrophe (')

This news story was inline of the earlier news headline in the context of the protests carried out by the religious parties in the country. This time, The Nation published the news headline by quoting the statement of the Prime Minister while Dawn published its headline by using the lexicalization in the form of the word "confronting".

The news headline of The Nation shows the writ of the state and the warning issued by the Prime Minister while the headline of Dawn just showed the warning. News of The Nation this time was more specific than Dawn.

It was found that both the news headlines portrayed the protesters as the out-groups which mean both the newspapers have used the polarization in their headlines while the lexicalization was used by Dawn as "confronting" which means to face especially in the hard time. 


\section{Urdu News Headlines \\ Headline 01}

Actor: Aasia

Authority: Supreme Court

Metaphor: "Maloona"

Punctuation: Comma (,)

Daily Jang

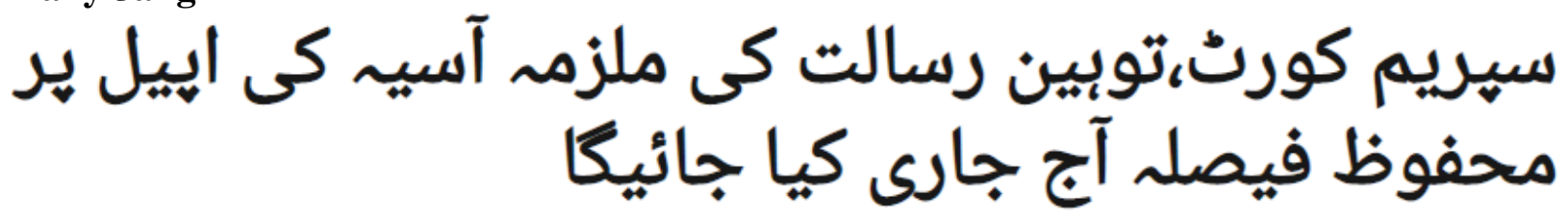

\section{Daily Ummat}

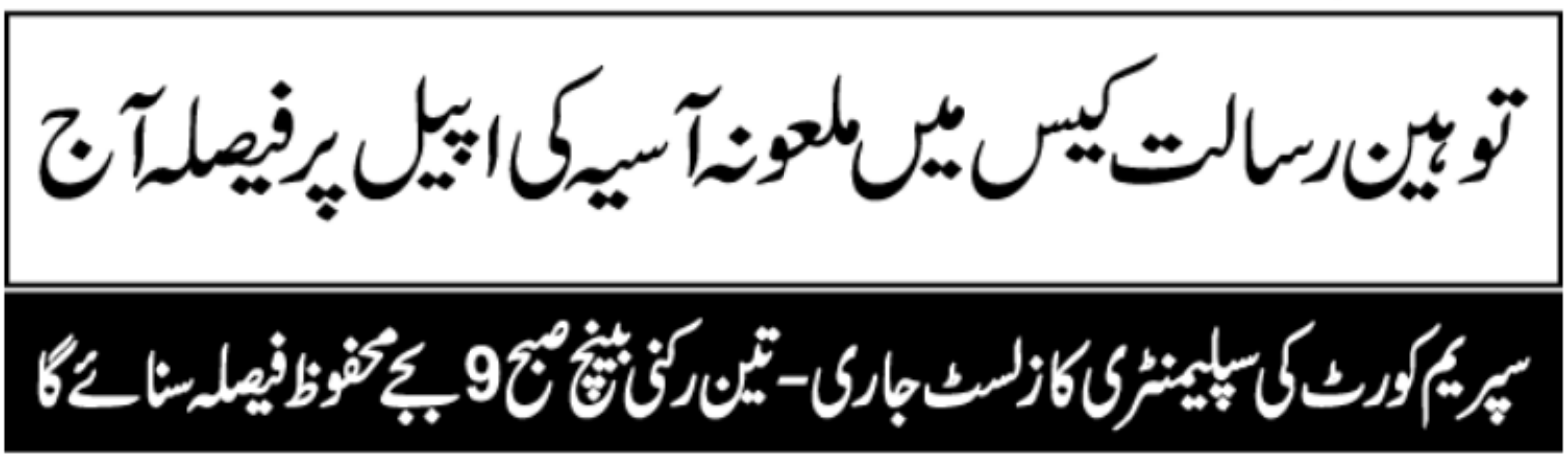

This news report again is in the context pre-judgment and disclaimer in sense. Both the newspapers covered the news headlines in same manner however the Daily Ummat used an offensive and subjective remarks in their news headlines. The news headlines of Daily Jang were specific and accurate while the Daily Ummat news headline was detailed.

The Daily Ummat used a metaphor for the Aasia in their which is "Maloona" which means accursed or execrable. This shows the subjective and offensive language of the newspaper despite the Aasia's appeal decision was in pending. Shah and Mubarak (2002) witnessed the same changings in the phrases in their news headlines to portray the headlines in different discursive manner with reference to their inclination whereas the Fang (2001) found the same difference in their lexical and syntactic structure. 


\section{Headline 02}

Actor: Aasia

Authority: Supreme Court

Punctuation: Comma (,)

\section{Daily Jang}

$$
\begin{aligned}
& \text { آسي توبين رسالت كح الزام سه برى، كوابوس كـ بيانات }
\end{aligned}
$$

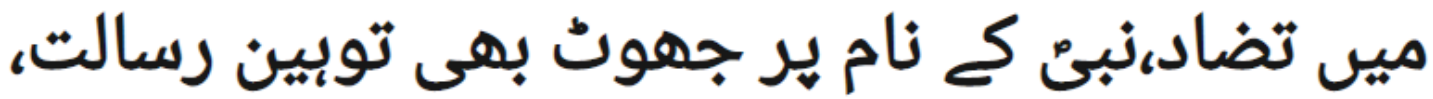

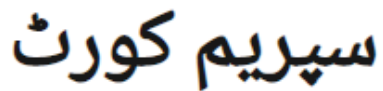

Daily Ummat

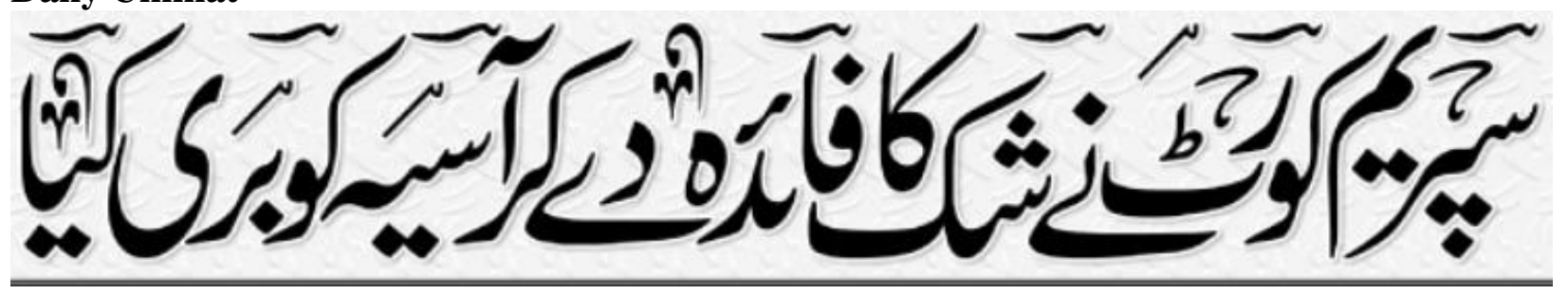

These news headlines of both the selected newspapers are of the judgment that was announced by the Supreme Court to acquit Aasia. The Daily Jang published this news headline with the statement and remarks of the Supreme Court in their judgment while the Daily Ummat published their news headline as a statement. Dearing and Rogers (1996) believe that a journalists role is to impartial and objective not inclined or subjective towards anything This statement of the news headline is subjective in nature which states that the Aasia was released on the benefit of the doubt.

\section{Headline 03}

Actor: Aasia, United Nation. America, British PM

Punctuation: Comma (,)

Metaphor: Gustakh, Maloona

Daily Jang

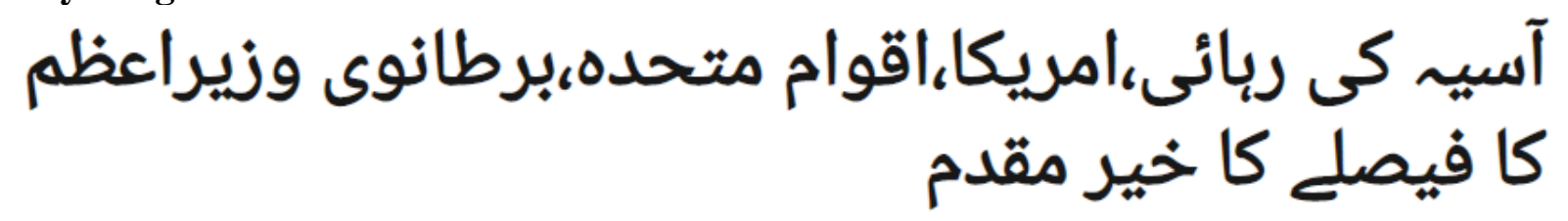




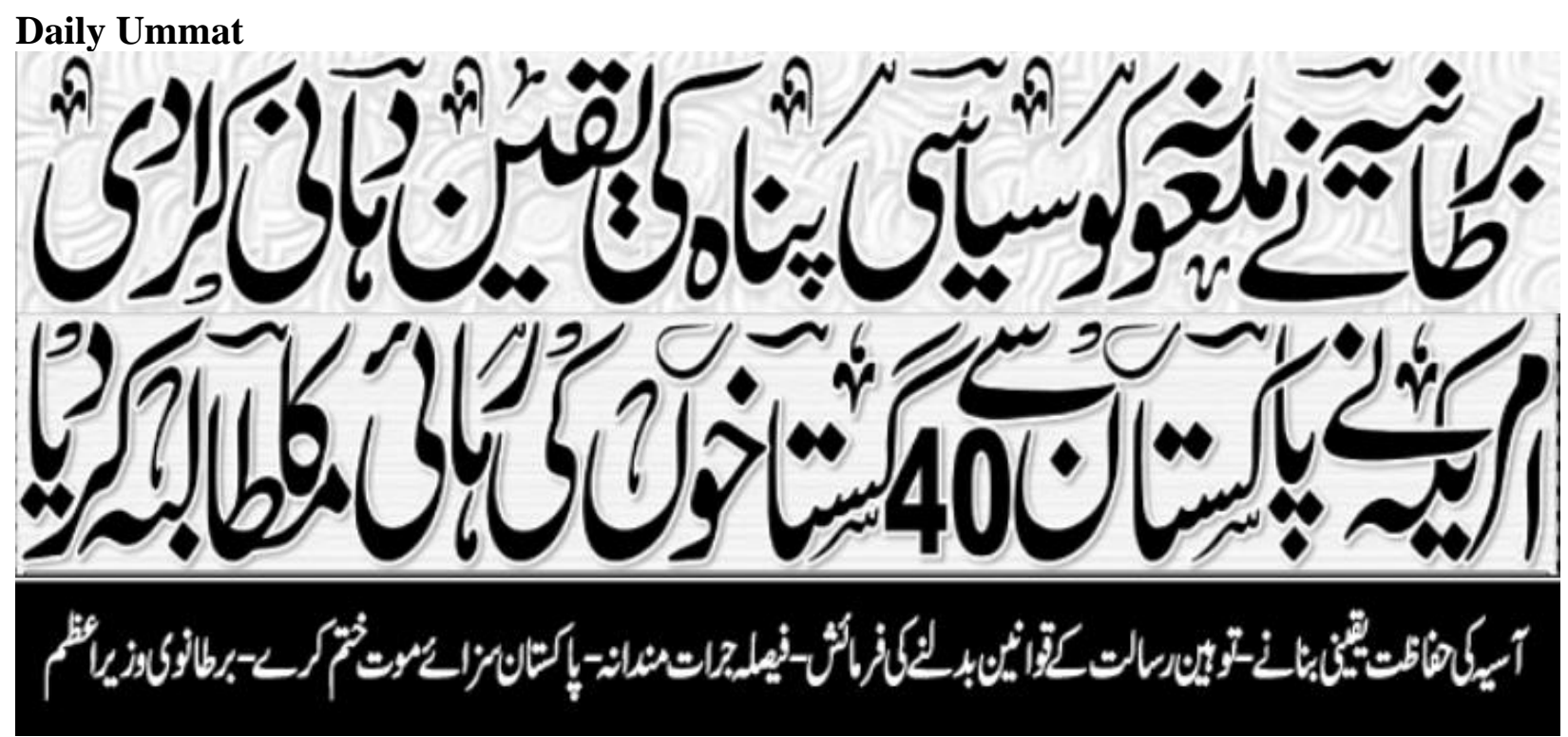

These headlines are about the statements issued in favor of the acquittal of Aasia Bibi. Daily Jang covered the purpose of the statements through single news headlines while the Daily Ummat again used an offensive and subjective language. Daily Ummat used the words "Maloona" and "Gustakh" which means the sinner and execrable. Greer (2003) believes that news is seen in the cultural setting and the cultural proximity. These words and discursive techniques are in the cultural proximity and the main reason behind this usage of language is because of the religious inclination and orientation of the issue whereas Sajid et al. (1996) states that the headlines are not ideologically free, they are shaped according to the ideological orientations and sentiments.

As it was observed that as compared to single news headline of Daily Jang, Daily Ummat not only published two different news headlines but also exaggerated them with the usage of the linguistic techniques and subjective remarks.

\section{Headline 04}

Authority: Government

Punctuation: Comma (,)

Number Game: 144, 10 days

Lexicalization:

Daily Jang 


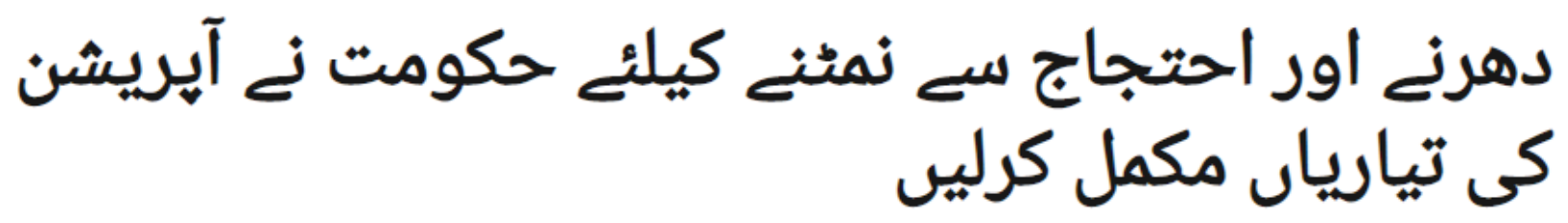

Daily Ummat

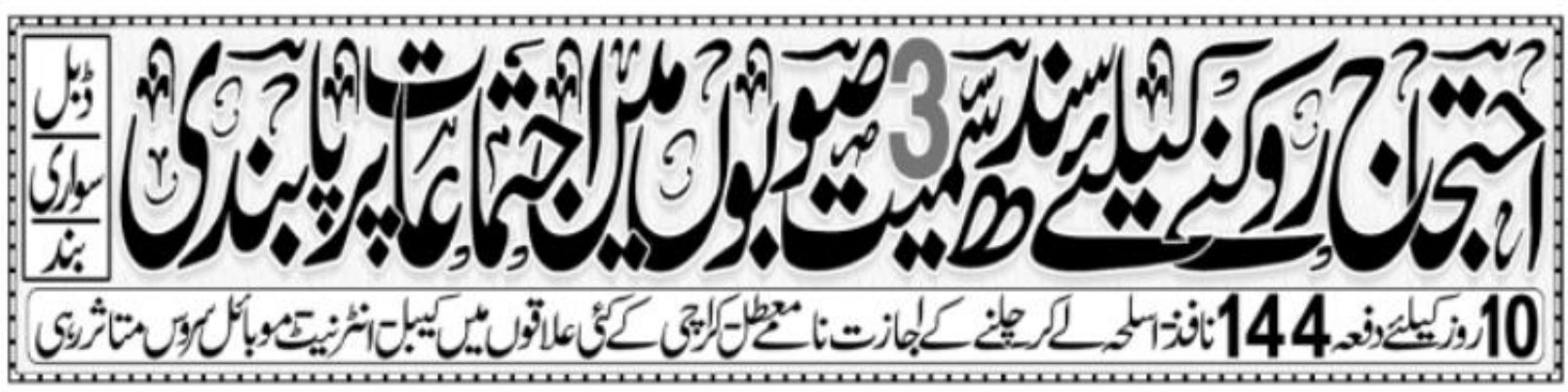

Both news headlines are in the context of the protests and the preventive measures by the government as covered by the English newspapers. Daily Jang published the news that the Government has made the preparations for the operation against the protestors. It is pertinent to note the lexical choice used by both the newspapers. Daily Jang used the word "Nipatnay" which means "to deal with" while the Daily Ummat used "Roknay" which refers to stopping someone. Daily Ummat covered the news in its religious perspective and in the provincial power structure by naming the Sindh province and others.

It was observed that ten days ban on licensed weapons and other facts were mentioned by the Daily Ummat. Moreover, they used the phrase "Ijtimaat par pabandi" which can be referred and translated in many forms. Usually, this term defined as the religious gatherings as the word "Ijtima" means a large gathering. However, this term is often used by the religious seminary events and gatherings in Pakistani Context.

\section{Conclusion}

Results of this research study reveal a wide range of lexical choices and discursive techniques used in the news headlines which helps to disseminate the desire ideologies and to make the representation of text in different manner. It was also observed that the newspapers like Dawn and Daily Jang were sensible and objective in covering the news headlines while The Nation and Daily Ummat used offensive and subjective remarks to twist the news headlines and propagated the desired narratives. It was discovered that 
these two newspapers used the lexical choices to manipulate the event and represented it in a different manner.

Findings clearly highlight that the news headlines are not ideologically free, but they are biased or framed to some extent for the certain purposes. The newspapers make in and out groups as seen in the polarization of the news context. This research study proved that the newspapers with the help of the discursive techniques and lexical choice reshaped the news headlines in newspapers to build public opinions. It was found that the same event was manipulated with the help of discursive practice and represented differently in diverse newspapers. 


\section{References}

Ali, G. A. (2011). Hero or terrorist? A comparative analysis of Arabic and Western media depictions of the execution of Saddam. Discourse \& Communication, 5(4), 301335 .

Bell, A. (1991). The language of news media (pp. 84-85). Oxford: Blackwell. Blasphemy. 2020. In Merriam-Webster.com Retrieved April 11, 2020, from https://www.merriam-webster.com/dictionary/blasphemy

Chermak, S. M. (1995). Victims in the news: Crime and the American news media. Boulder, CO: Westview Press.

Chyi, H. I., \& McCombs, M. (2004). Media salience and the process of framing: Coverage of the Columbine school shootings. Journalism \& Mass Communication Quarterly, 81(1), 22-35.

Cohen, S., \& Young, J. (1973). The manufacture of news. Beverly Hills.

Cooky, C., Dycus, R., \& Dworkin, S. L. (2013). "What Makes a Woman a Woman?" Versus "Our First Lady of Sport" A Comparative Analysis of the United States and the South African Media Coverage of Caster Semenya. Journal of Sport and Social Issues, 37(1), 31-56.

Cottle, S. (2000). Ethnic minorities \& the media: Changing cultural boundaries. McGraw-Hill Education (UK).

Dawn (2018, Oct 18). Supreme Court acquits Aasia Bibi, orders immediate release. Retrieved from https://www.dawn.com/news/1442396

Dawn (2019, Jan 28). Aasia Bibi's final hurdle comes to an end as SC upholds her acquittal. Retrieved from https://www.dawn.com/news/1460376

Dearing, J. W., Rogers, E. M., \& Rogers, E. (1996). Agenda-setting (Vol. 6). Sage.

Dor, D. (2003). On newspaper headlines as relevance optimizers. Journal of Pragmatics, 35(5), 695-721. 
Portrayal of Aasia Bibi Blasphemy Case ...

Eijaz, A. (2010). Media representations and social meanings of blasphemy laws in Pakistan. International Journal of Muslim Unity, 8(1-2), 47-71.

Entman, R. M. (1993). Framing: Toward clarification of a fractured paradigm. Journal of communication, 43(4), 51-58.

Ferman, D. (2013). A parade or a riot: A discourse analysis of two ethnic newspapers on the 2011 marching season in Northern Ireland. Journal of Media and Religion, 12(2), 55-70.

Fowler, R. (1991). Language in the news: Discourse and ideology in the press Routledge. London and New York.

Gamson, W. A., \& Modigliani, A. (1989). Media discourse and public opinion on nuclear power: A constructionist approach. American journal of sociology, 95(1), 1-37.

Gitlin, T. (1980). The Whole World Is Watching (Berkeley, Calif.

Goffman, E. (1974). Frame analysis: An essay on the organization of experience. Harvard University Press.

Gopang, I. B., \& Bughio, F. A. (2017). Pakistani Budget 2013-2014: A Critical Discourse Analysis. International Journal of English language teaching. Retrieved from https. www. researchgate. net/publication/281237843 on the 1st of Dec.

Greer, C. (2003). Sex Crime and the Media: Sex offending and the Press. A Divided Societ.

Harcup, T. (2002). Journalists and ethics: The quest for a collective voice. Journalism Studies, 3(1), 101-114.

Jiwani, Y. (2006). Missing and murdered women: Reproducing marginality in news discourse. Canadian journal of communication, 31(4).

Khodabandeh, F. (2007). A Contrastive Analysis of English and Persian Newspaper Headlines. Linguistics Journal, 2(1). 


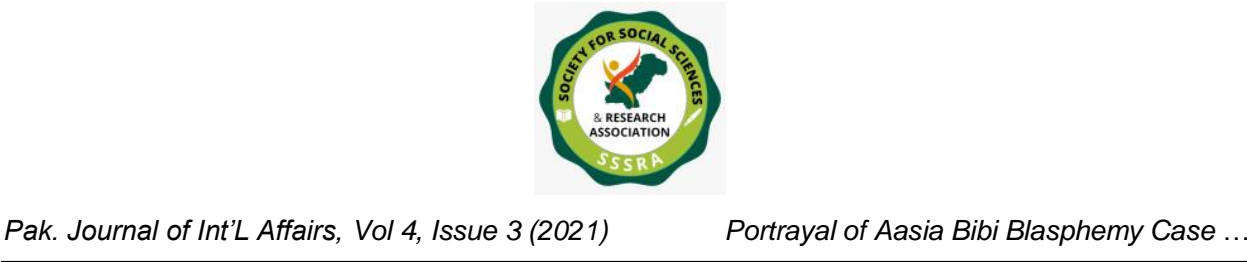

Kirange, D. K., \& Deshmukh, R. R. (2016). Sentiment Analysis of News Headlines for Stock Price Prediction. Composoft, An International Journal of Advanced Computer Technology, 5(3), 2080-2084.

Lee, H. K. (2009). On the headlines of English and Korean political news articles. 언어연구, 26(1), 67-87.

Lee, H. K. (2012). Linguistic variations between English news headlines in the US and those in Korea. Linguistic Research, 29(2), 329-350.

Merriam-Webster. (n.d.). Erupt. In Merriam-Webster.com dictionary. Retrieved April 17, 2020, from https://www.merriam-webster.com/dictionary/erupt

Merriam-Webster. (n.d.). Paralyze. In Merriam-Webster.com dictionary. Retrieved April 17, 2020, from https://www.merriam-webster.com/dictionary/paralyze

Neiger, M. (2007). Media oracles: The political import and cultural significance of news referring to the future. Journalism: Theory, practice \& criticism, 8(3), 326-338.

Nir, R. (1993). Discourse analysis of news headlines. Balšanwt iybriyt, (37), 23-31.

Noorani, A. G. (1990). Jinnah's Commitment to Liberalism. Economic and Political Weekly, 71-73.

Pakistan Penal Code, (PPC): Offences Relating to Religion. Chapter 15, Section 295

Polymenopoulou, E., \& Rehman, J. (2013). Recent developments in Pakistan: blasphemy laws, religious minorities and the case of Aasia Bibi.

Quirk, R., Greenbaum, S., Leech, G., \& Svartvik, J. (1985). A Comprehensive grammar of the English language, decimosexta reimpresión.

Reah, D. (2002). The language of newspapers. Psychology Press.

Sajid, M. A., Anwar, B., \& Ashraf, M. (2019). Politics, Ideology and Print Media: A CDA of Newspapers' Headlines.

Shah, S. K., \& Mubarak, A. (2018). Media discourse as representative of sociocultural milieu of law and order in Pakistan: A critical discourse analysis of newspapers' 
headlines about Model Town tragedy, Lahore. Pakistan Journal of Language Studies, 2(1).

Shie, J. S. (2011). Metaphors and metonymies in New York Times and Times Supplement news headlines. Journal of pragmatics, 43(5), 1318-1334.

Taiwo, R. (2007). Language, Ideology and Power Relations in Nigerian Newspaper Headlines. Nebula, 4(1).

Teo, P. (2000). Racism in the news: A critical discourse analysis of news reporting in two Australian newspapers. Discourse \& society, 11(1), 7-49.

Ulum, O. G. (2016). Newspaper Ideology: A Critical Discourse Analysis of News Headlines on Syrian Refugees in Published Newspapers. Turkish Studies, 11(5), 541-552.

Van Dijk, T. A. (2006). Politics, ideology, and discourse.

Van Dijk, T. A. (Ed.). (1998). Discourse as structure and process (Vol. 1). Sage. 